\title{
Efisiensi dan produktivitas industri perbankan pada sistem moneter ganda di Indonesia
}

\author{
Aam Slamet Rusydiana ${ }^{1 *}$, Nisful Laila ${ }^{2}$, Sudana ${ }^{3}$ \\ ${ }^{1}$ Peneliti pada Sharia Economic Applied Research \& Training (SMART) Indonesia. \\ ${ }^{2}$ Fakultas Ekonomi dan Bisnis Universitas Airlangga, Surabaya, Indonesia \\ ${ }^{3}$ Program Doktoral Universitas Islam Negeri Bandung, Bandung, Indonesia \\ *Corresponding author: aamsmart@gmail.com
}

\begin{abstract}
This study aims to examine the level of efficiency of 115 commercial banks in Indonesia for the period between 2010 and 2016. We use basic models of Data Envelopment Analysis (DEA) consisting of CCR (Charnes Cooper Rhodes) and BCC (Banker Charnes Cooper) models. This study also investigate the value of productivity of each bank which is then compared. The study finds that commercial banks in Indonesia exhibit an increase in productivity although it is relatively small. The stagnation of the level of productivity is due to the low level of technological change (technological change) rather than a decrease in efficiency (Efficiency change). Another interesting finding is that around 70 percent of the hypothetically relative credit market share in Indonesia is controlled by only 29.56 percent of commercial banks. This also means that around 30 percent of the remaining credit market share is contested by the rest of other banks.
\end{abstract}

Keywords: Efficiency, productivity, DEA, Malmquist, banking industry, Indonesia

\begin{abstract}
Abstrak
Penelitian ini bertujuan untuk menguji tingkat efisiensi 115 bank umum di Indonesia untuk periode antara 2010 dan 2016. Studi ini menggunakan model dasar Analisis Envelopment Data (DEA) yang terdiri dari model CCR (Charnes Cooper Rhodes) dan BCC (Banker Charnes Cooper). Penelitian ini juga menyelidiki tentang nilai produktivitas masing-masing bank yang diteliti. Studi ini menemukan bahwa bank komersial di Indonesia menunjukkan peningkatan produktivitas walaupun relatif kecil. Stagnasi tingkat produktivitas tersebut lebih banyak disebabkan oleh rendahnya tingkat perubahan teknologi (technological change) dari pada oleh penurunan efisiensi (Efficiency change). Temuan menarik lainnya adalah bahwa sekitar 70 persen pangsa pasar kredit di Indonesia dikuasai oleh hanya sebanyak 29,56 persen bank umum. Hal ini juga berarti bahwa sekitar 30 persen dari pangsa pasar kredit yang tersisa diperebutkan oleh bank-bank lain.
\end{abstract}

Kata kunci: Efisiensi, produktivitas, DEA, Malmquist, industri perbankan, Indonesia JEL Code: G21 DOI: $10.20885 /$ jsb.vol23.iss1.art5

\section{Pendahuluan}

Secara umum perbankan Indonesia bertujuan menunjang pelaksanaan pembangunan nasional dalam rangka meningkatkan pemerataan, pertumbuhan ekonomi, dan stabilitas nasional ke arah peningkatan kesejahteraan rakyat banyak. Perbankan Indonesia beroperasi dalam dual-banking system atau sistem perbankan ganda dalam kerangka Arsitektur Perbankan Indonesia (API) sehinga dapat menghadirkan alternatif jasa perbankan yang semakin lengkap kepada masyarakat. Secara bersama-sama, sistem perbankan syariah dan perbankan konvensional secara sinergis mendukung mobilisasi dana masyarakat secara lebih luas untuk meningkatkan kemampuan pembiayaan bagi sektor-sektor perekonomian nasional.

Perbankan menjadi tulang punggung perekonomian negara Indonesia dan bank mempunyai peranan penting sebagai lembaga intermediary (perantara) antara pihak yang kelebihan dana (surplus unit) yang menyimpan kelebihan dananya di bank, dengan pihak yang kekurangan dana (deficit unit) 
yang meminjam dana ke bank. Fungsi intermediasi ini akan berjalan dengan baik jika surplus unit maupun deficit unit memiliki kepercayaan kepada bank. Berjalannya fungsi intermediasi oleh bank akan meningkatkan efisiensi dan optimalitas penggunaan dana. Dana yang dihimpun dari surplus unit oleh bank selanjutnya akan disalurkan dalam bentuk pinjaman kepada deficit unit dalam berbagai bentuk aktivitas produktif.

Dalam implementasi dual banking system di perbankan nasional, perlu adanya pengidentifikasian dan pengkajian stabilitas sistem keuangan dan kinerja (kesehatan) lembagalembaga keuangan agar dapat dikelola dengan baik. Selanjutnya gejala-gejala krisis dapat teridentifikasi sedemikian rupa sehingga kerugian yang potensial diderita oleh masyarakat Indonesia akibat krisis yang mungkin terjadi dapat diminimalkan. Nurfalah et al. (2018) dan Rani et al. (2017) misalnya melakukan pengamatan terkait sistem deteksi dini krisis perbankan pada sistem moneter ganda, termasuk mengukur tingkat produktivitas industri perbankan di Indonesia.

Perkembangan industri perbankan syariah di Indonesia relatif menunjukkan kecenderungan yang baik, meskipun terkesan lambat. Data Bulan April 2018, berdasarkan statistik perbankan syariah, jumlah perbankan syariah telah mencapai 13 Bank Umum Syariah, 21 Unit Usaha Syariah dan 168 Bank Pembiayaan Rakyat Syariah dengan total jaringan kantor sebanyak 2,460 kantor di seluruh Indonesia (Otoritas Jasa Keuangan, 2018). Sedangkan, menurut Global Islamic Finance Report 2017, industri keuangan syariah di Indonesia berada di urutan ke tujuh dunia setelah Malaysia, Iran, Arab Saudi, UAE, Kuwait dan Pakistan. Score indeks industri keuangan syariah Indonesia pada 2017 adalah 24.21 pada skala 100 dan menempati urutan ke-7 di dunia (GIFR, 2017).

Menurut Kamath (2007) sektor perbankan syariah merupakan sektor bisnis yang bersifat "intellectually intensive" dan juga termasuk sektor jasa, di mana layanan pelanggan sangat bergantung pada intelektual dan kecerdasan modal manusia (Maisaroh, 2015). Maka dari itu Perbankan Syariah masih memerlukan SDM yang berkualitas untuk dapat meningkatkan produktivitas dan efisiensi kinerja perbankan syariah sehingga dapat mempengaruhi tingkat profitabilitas.

Terlepas dari data tersebut, Bank Indonesia telah mentarget pangsa pasar perbankan Syariah pada tahun 2016 mencapai market share 5\%. Akan tetapi, target capaian tersebut belum terlaksana sehingga dapat dikatakan bahwa kinerja bank Syariah secara keseluruhan belum memuaskan. Pertumbuhan yang terjadi pada bank syariah tidak lebih baik jika dibandingkan dengan peningkatan market share bank syariah itu sendiri. Target market share bank syariah tahun 2016 yang tidak tercapai menjadi suatu fenomena tersendiri untuk mengevaluasi tingkat kinerja efisiensi perbankan syariah di Indonesia. Perbankan Syariah masih menghadapi beberapa macam hambatan seperti faktor kompetisi dan konversi unit usaha syariah menjadi bank umum Syariah. Disamping itu, tingginya nilai investasi yang harus dikeluarkan menyebabkan ketidakefisienan dalam head to head dengan perbankan konvensional.

Motivasi utama untuk reformasi sektor perbankan termasuk bank syariah adalah untuk mendorong sector perbankan dalam kerangka regulasi dan hukum, monitoring dan supervisi, manajemen risiko pembiayaan, manajemen likuiditas, auditing dan aspek penting lainnya. Jika reformasi sektor perbankan berjalan baik, maka hal ini akan mampu meningkatkan efisiensi sektor perbankan yang berpengaruh pada setiap aspek operasional bank. Bank yang efisien kemudian mampu mengurangi biaya dan mengenakan marjin yang relatif rendah terhadap nasabah.

Penelitian ini memiliki 2 (dua) tujuan utama. Pertama mengukur tingkat efisiensi industri perbankan di Indonesia, baik bank konvensional maupun bank syariah. Kedua, menganalisis tingkat produktivitas industri perbankan nasional yang menjadi objek penelitian. Salah satu kebaruan dalam penelitian ini adalah penulis ingin melihat apakah sumber peningkatan atau penurunan produktivitas perbankan berasal dari perubahan tingkat efisiensi yang dicapai oleh setiap bank ataukah berasal dari perubahan teknologi (technical changes) yang digunakan bank. Hal ini kemudian akan penulis kaitkan dengan fenomena inovasi teknologi keuangan (financial technology) pada industri perbankan khususnya di Indonesia. 


\section{Landasan Teori}

Konsep efisiensi seringkali didefinisikan sebagai melakukan sesuatu secara benar (doing the thing right). Hal ini biasanya selalu dikaitkan dengan bagaimana cara perusahaan dalam mencapai tujuannya. Oleh karena itu, konsep efisiensi seringkali dilihat dari sisi biaya sebagai input dan keuntungan sebagai output. Entitas bisnis selalu berusaha agar tingkat biaya ditekan sampai pada level seminimal mungkin untuk menghasilkan tingkat output berupa keuntungan yang maksimal.

Konsep efisiensi berasal dari konsep mikro ekonomi yaitu teori produsen. Teori produsen mencoba untuk memaksimumkan keuntungan atau meminimumkan biaya dari sudut pandang produsen. Pada teori produsen tersebut terdapat kurva batas produksi (production frontier curve) yang menggambarkan hubungan antara input dan output dari proses produksi. Kurva frontier produksi ini mewakili tingkat output maksimum dari setiap penggunaan input yang mewakili penggunaan teknologi dari suatu perusahaan atau industri (Ascarya dan Yumanita, 2007).

Pada teori ekonomi terdapat dua jenis efisiensi, yaitu efisiensi ekonomi (economic efficiency) dan efisiensi teknik (technical efficiency). Efisiensi ekonomi mempunyai gambaran ekonomi makro, sedangkan efisiensi teknik memiliki gambaran ekonomi mikro. Pengukuran efisiensi teknik hanya untuk teknik dan hubungan operasional dalam proses penggunaan input menjadi output. Term efisiensi dalam DEA lebih merujuk definisi efisiensi teknis, yakni hubungan antara input dan output pada sebuah unit bisnis.

Sementara itu dalam sudut pandang perusahaan dikenal tiga macam efisiensi, yaitu: efisiensi teknis, efisiensi alokatif dan efisiensi ekonomi. Technical Efficiency merefleksikan kemampuan perusahaan untuk mencapai level output yang optimal dengan menggunakan tingkat input tertentu. Efisiensi ini mengukur proses produksi dalam menghasilkan sejumlah output tertentu dengan menggunakan input seminimal mungkin. Dengan kata lain, suatu proses produksi dikatakan efisien secara teknis apabila output dari suatu barang tidak dapat lagi ditingkatkan tanpa mengurangi output dari barang lain.

Allocative Efficiency, merefleksikan kemampuan perusahaan dalam mengoptimalkan penggunaan input dengan struktur harga dan teknologi. Terminologi efisiensi Pareto sering disamakan dengan efisiensi alokatif untuk mengembangkan konsep efficiency in exchange. Efisiensi Pareto mengatakan bahwa input produksi digunakan secara efisien apabila input tersebut tidak mungkin lagi digunakan untuk meningkatkan suatu usaha tanpa menyebabkan setidak-tidaknya keadaan suatu usaha yang lain menjadi lebih buruk. Dengan kata lain, apabila input dialokasikan untuk memproduksi output yang tidak dapat digunakan atau tidak diinginkan konsumen, hal ini berarti input tersebut tidak digunakan secara efisien.

Adapun Economic Efficiency, menggambarkan kombinasi antara efisiensi teknikal dan efisiensi alokatif. Efisiensi ekonomis secara implisit merupakan konsep least cost production. Untuk tingkat output tertentu, suatu perusahaan produksinya dikatakan efisien secara ekonomi jika perusahaan tersebut menggunakan biaya dimana biaya per unit dari output adalah yang paling minimal. Dengan kata lain, untuk tingkat output tertentu, suatu proses produksi dikatakan efisien secara ekonomi jika tidak ada proses lainnya yang dapat digunakan untuk memproduksi tingkat output tersebut pada biaya per unit yang paling kecil.

Seiring berjalannya waktu, model pengukuran efisiensi frontier telah meningkat, baik secara konsep teori maupun praktik. Secara umum, model pengukuran tingkat efisiensi terbagi menjadi dua bagian yakni parametric dan nonparametric. Berikut ini adalah gambaran umum perkembangan model pengukuran efisiensi frontier yang berhasil penulis identifikasi. 
Tabel 1. Perkembangan Analisis Model Pengukuran Efisiensi Frontier (Rusydiana, 2018).

\begin{tabular}{|c|c|c|c|c|}
\hline NO & MODEL & $\begin{array}{c}\text { TAHU } \\
\mathrm{N}\end{array}$ & PENULIS & TIPE \\
\hline 1 & Stochastic Frontier Approach als77 & 1977 & Aigner, Lovell, Schmidt & Parametrik \\
\hline 2 & SFA Model mvb77 & 1977 & Meeusen \& van den Broeck & Parametrik \\
\hline 3 & Data Envelopment Analysis CCR & 1978 & Charnes, Cooper, Rhodes & Nonparametrik \\
\hline 4 & SFA Model stev80 & 1980 & Stevenson & Parametrik \\
\hline 5 & SFA Model mlti & 1981 & Pitt \& Lee & Parametrik \\
\hline 6 & Malmquist Productivity Index & 1982 & Caves, Christensen, Diewert & Nonparametrik \\
\hline 7 & DEA Model BCC & 1984 & Banker, Charnes, Cooper & Nonparametrik \\
\hline 8 & Free Disposal Hull [FDH] & 1984 & Deprins, Simar, Tulkens & Nonparametrik \\
\hline 9 & SFA Model fe & 1984 & Schmidt \& Sickles & Parametrik \\
\hline 10 & SFA Model regls & 1984 & Schmidt \& Sickles & Parametrik \\
\hline 11 & DEA Additive Model & 1985 & $\begin{array}{l}\text { Charnes, Cooper, Golany, } \\
\text { Seiford, Stutz }\end{array}$ & Nonparametrik \\
\hline 12 & DEA Window Analysis & 1985 & $\begin{array}{l}\text { Charnes, Clarke, Cooper, } \\
\text { Golany }\end{array}$ & Nonparametrik \\
\hline 13 & DEA Assurance Region [DEA-AR] & 1986 & $\begin{array}{l}\text { Thompson, Singleton, Thrall, } \\
\text { Smith }\end{array}$ & Nonparametrik \\
\hline 14 & DEA Cross Efficiency & 1986 & Sexton, Silkman, Hogan & Nonparametrik \\
\hline 15 & DEA Facet Model & 1988 & Bessent, Bessent, Elam, Clark & Nonparametrik \\
\hline 16 & SFA Model mlti & 1988 & Battese \& Coelli & Parametrik \\
\hline 17 & SFA Model fecss & 1990 & Cornwell, Schmidt, Sickles & Parametrik \\
\hline 18 & SFA Model kumb90 & 1990 & Kumbhakar & Parametrik \\
\hline 19 & DEA Cone Ratio & 1990 & Charnes, Cooper, Huang, Sun & Nonparametrik \\
\hline 20 & TFA [Thick Frontier Approach] & 1991 & Berger \& Humphrey & Parametrik \\
\hline 21 & SFA Model bc92 & 1992 & Battese \& Coelli & Parametrik \\
\hline 22 & Fuzzy DEA & 1992 & Sengupta & Nonparametrik \\
\hline 23 & DFA [Distribution Free Approach] & 1993 & Berger & Parametrik \\
\hline 24 & SFA Model fels & 1993 & Lee \& Schmidt & Parametrik \\
\hline 25 & DEA Super Efficiency & 1993 & Andersen \& Peterson & Nonparametrik \\
\hline 26 & SFA Model bc95 & 1995 & Battese \& Coelli & Parametrik \\
\hline 27 & Network DEA & 1996 & Fare \& Grosskopf & Nonparametrik \\
\hline 28 & Hierarchical/Nested Model DEA & 1998 & Cook, Chai, Doyle, Green & Nonparametrik \\
\hline 29 & Bootstrapped DEA & 1998 & Simar \& Wilson & Parametrik \\
\hline 30 & DEA Russell Measure [ERM] & 1999 & Pastor, Ruiz, Sirvent & Nonparametrik \\
\hline 31 & Imprecise Data [IDEA] & 1999 & Cooper, Park, Yu & Nonparametrik \\
\hline 32 & Parallel Model DEA & 2000 & Cook, Hababou, Tuenter & Nonparametrik \\
\hline 33 & Dynamic DEA & 2000 & Fare \& Grosskopf & Nonparametrik \\
\hline 34 & DEA Slack Based Measure [SBM] & 2001 & Tone & Nonparametrik \\
\hline 35 & Meta Frontier & 2003 & Rao, O'Donnel, Battese & Nonparametrik \\
\hline 36 & Context-Dependent DEA & 2003 & Seiford \& Zhu & Nonparametrik \\
\hline 37 & SFA Model gre03 & 2003 & Greene & Parametrik \\
\hline 38 & SFA Model tfe & 2005 & Greene & Parametrik \\
\hline 39 & SFA Model tre & 2005 & Greene & Parametrik \\
\hline 40 & Game Cross Efficiency & 2008 & Liang, Wu, Cook, Zhu & Nonparametrik \\
\hline
\end{tabular}

\section{Penelitian Terdahulu}

Studi yang relatif relevan dengan penelitian ini adalah yang dilakukan oleh Shawtari et al. (2014). Dengan menggunakan pendekatan Data Envelopment Windows Analysis (DEWA), Shawtari et al. (2014) mencoba menganalisis efisiensi industri perbankan di Yaman untuk periode 1996 hingga 2011. Temuannya mengindikasikan bahwa industri perbankan di Yaman secara umum mengalami tren penurunan dan instabilitas efisiensi selama periode penelitian. Hasil studi juga menemukan 
bahwa mayoritas bank konvensional Yaman relatif lebih stabil meskipun tidak efisien. Sementara itu bank Islam dan bank asing lebih efisien dari waktu ke waktu. Adapun bank milik Negara dan bank swasta relatif tertinggal dari sisi pencapaian tingkat efisiensi.

Penelitian Hadad et al. (2003) yang menganalisis efisiensi industri perbankan Indonesia dengan metode non parametrik DEA, menunjukkan bahwa kelompok bank swasta nasional non devisa merupakan yang paling efisien selama tiga tahun (2001-2003) dalam kurun analisis delapan tahun (1996-2003) dibandingkan bank-bank lainnya. Terdapat tiga poin penting dari hasil penelitiannya yaitu: pertama, kredit yang terkait dengan bank dan surat berharga mempunyai potensi pengembangan sangat tinggi untuk meningkatkan efisiensi secara keseluruhan; kedua, merger dari bank tidak selamanya membuat bank menjadi lebih efisien; dan ketiga, kelompok bank swasta nasional non-devisa merupakan bank yang paling efisien selama 3 tahun (2001-2003) dalam kurun analisis 8 tahun (1996-2003) dibanding bank-bank lainnya. Bank asing campuran adalah bank yang paling efisien tahun 1997, sedangkan bank swasta nasional devisa mencapai tingkat efisiensi tertinggidi pada tahun 1998 dan 1999.

Terkait bank syariah, Yudistira (2003) melakukan penelitian terhadap 18 bank syariah di seluruh dunia selama periode 1997-2000 dengan menggunakan pendekatan DEA dan spesifikasi input-output berdasarkan pendekatan intermediasi. Berdasarkan hasil penelitian menunjukkan bahwa secara keseluruhan efisiensi 18 bank syariah yang diobservasi mengalami sedikit inefisiensi di tingkat wajar 10\% jika dibandingkan dengan bank konvensional. Hal ini disebabkan karena periode 19981999 bank-bank konvensional mengalami krisis global sehingga mempengaruhi kinerjanya. Sementara itu, bank syariah yang berskala kecil cenderung tidak ekonomis dan dianjurkan agar melakukan merger atau akuisisi.

Penelitian tentang efisiensi bank Islam didukung oleh penelitian Hassan (2003), dalam penelitiannya yang menguraikan tentang cost, profit, revenue, dan X-efficiency dari bank Islam di seluruh dunia. Pertama, penelitian tersebut membuat sebuah pendekatan stochastic cost frontier untuk menghitung cost efficiency dari bank Islam pada periode 1996-2002. Kedua, menghitung profit efficiency dengan memperhatikan cost dan revenue. Ketiga, menentukan revenue efficiency untuk mengetahui apakah bank Islam membuat inovasi produk perbankan untuk meningkatkan pendapatannya. Keempat, menggunakan metode non parametrik Data Envelopmnet Analysis (DEA) untuk menghitung keseluruhan efisiensi, yaitu technical, pure technical, allocative, dan scale efficiency. Hasilnya adalah secara rata-rata, industri bank Islam adalah relatif kurang efisien dibandingkan dengan bank konvensional.

Penelitian yang sama dengan menggunakan DEA dilakukan oleh Ascarya dan Yumanita (2007), penelitian dengan menggunakan pendekatan DEA terhadap perbankan syariah di Indonesia selama periode 2000-2004. Hasil penelitian menunjukkan bahwa efisiensi relatif secara teknis bank syariah dengan pendekatan intermediasi (100\%) dan produksi (85\%) pada tahun 2004. Demikian juga efisiensi relatif secara skala dari pendekatan intermediasi (87\%) dan produksi (97\%). Secara umum dari pendekatan produksi bank syariah mengalami penurunan efisiensi teknis, namun mengalami peningkatan efisiensi skala karena pada saat itu bank syariah cukup agresif dalam berekspansi membuka kantor-kantor baru.

\section{Metodologi Penelitian}

Metode yang digunakan dalam penelitian ini adalah Data Envelopment Analysis (DEA). DEA adalah metode nonparametrik yang menggunakan model program linier untuk menghitung perbandingan rasio output dan input untuk semua unit yang diperbandingkan. Keuntungan dari penggunaan DEA ini adalah bahwa pendekatan ini tidak memerlukan spesifikasi yang eksplisit dari bentuk fungsi dan hanya memerlukan sedikit struktur untuk membentuk frontier efisiensinya. Kelemahan yang mungkin muncul adalah self identifier dan near self identifier. DEA dikembangkan pertama kali oleh Farrell (1957) yang mengukur efisiensi teknik satu input dan satu output menjadi multi input dan multi output. 
Data Envelopment Analysis (DEA) akan menghitung nilai $h s$, yaitu nilai efisiensi masingmasing periode perbankan syariah. Data Envelopment Analysis memaksimalkan nilai hs, dimana hs adalah jumlahan perkalian antara bobot output i dengan jumlah output i pada periode perbankan syariah s.

$$
h_{s}=\frac{\sum_{i=1}^{m} u_{i} y_{i s}}{\sum_{j=1}^{n} v_{j} x_{j s}}
$$

Di mana:

hs $=$ efisiensi bank $\mathrm{s}$

$m$ = output bank $s$ yang diamati

$n \quad$ = input bank $s$ yang diamati

yis $=$ jumlah output $i$ yang diproduksi oleh bank $s$

$x j s=$ jumlah input $j$ yang digunakan oleh bank $s$

$u i=$ bobot output $\mathrm{i}$ yang dihasilkan oleh bank $\mathrm{s}$

$v j=$ bobot input $j$ yang diberikan oleh bank $s$ dan $i$ dihitung dari 1 ke $m$ serta $j$ hitung dari 1 ke $n$

Selanjutnya, metode DEA banyak dipakai untuk mengukur tingkat efisiensi teknis, skala dan ekonomi industri bank dan lembaga keuangan (Coelli et al. (1998, 2005); Sherman \& Gold (1985); Cooper et al. (1999, 2002, 2010)). Penelitian serupa dilakukan oleh Hadad et al. (2003), Ozdemir (2013), Shahreki (2012) serta Tsolas dan Dimitris (2012). Namun saat ini, DEA juga mulai banyak digunakan dalam mengukur tingkat efisiensi lembaga non-bank, seperti: rumah sakit, universitas, kantor pajak, termasuk juga lembaga nonprofit (Rusydiana, 2013).

Sementara itu untuk produktivitas digunakan indeks Malmquist. Indeks Malmquist merupakan indeks bilateral yang digunakan untuk membandingkan teknologi produksi dua unsur ekonomi. Indeks Malmquist berlandaskan pada konsep fungsi produksi (production function) yang mengukur fungsi produksi maksimum dengan batasan input yang sudah ditentukan. Dalam perhitungannya, indeks ini terdiri atas beberapa hasil yaitu: efficiency change, technological change, pure efficiency change, and economic scale change.

Dalam model generasi pertama yang dikembangkan oleh Caves et.al (1982), ada 2 (dua) model indeks produktivitas Malmquist. Pertama adalah 'Malmquist input quantity index' dan kedua adalah 'Malmquist output quantity index'. Indeks kuantitas input Malmquist untuk sebuah unit produksi, pada waktu observasi $t$ dan $t+1$, untuk referensi teknologi pada periode $k, k=t$ dan $t+1$. Indeks kuantitas input Malmquist hanya mengukur perubahan kuantitas input yang diobservasi antara waktu t dan $\mathrm{t}+1$, dimana:

$$
M I_{k}\left(y_{k}, x_{t}, x_{t+1}\right)=\frac{E_{k}^{I}\left(y_{k}, x_{t}\right)}{E_{k}^{I}\left(y_{k}, x_{t+1}\right)}, k=t, t+1
$$

Data yang digunakan adalah seluruh Bank Umum Komersial baik konvensional maupun syariah periode 2010-2016 berjumlah 115 bank. Data variabel input dan output didapat dari laporan neraca dan laba rugi masing-masing bank. Tiga input dan tiga output digunakan untuk mengukur efisiensi dan profitabilitas bank umum. Sebagai variabel input adalah Dana Pihak Ketiga (DPK) (X1), Aktiva tetap (X2) dan Biaya tenaga kerja (X3). Sementara itu untuk variabel output yaitu Aktiva produktif (Y1), Pendapatan bunga/bagi hasil (Y2) dan Fee based income (Y3). Penggunaan DPK dan aktiva produktif dalam input-output karena penelitian ini menggunakan pendekatan intermediasi. Tabel 2 menjelaskan statistik deskriptif dari masing-masing variabel input dan output yang digunakan dalam penelitian ini.

Tools analysis yang digunakan dalam penelitian ini adalah MaxDEA 6.1 untuk mengukur tingkat efisiensi seluruh DMU bank syariah selama periode 2010-2016. Analisis untuk pengukuran efisiensi akan dilakukan 2 kali. Pertama penghitungan efisiensi dengan pendekatan CRS atau CCR yang dikenalkan Charnes et al. (1978). Model CCR (Charnes Cooper Rhodes) ini adalah model 
pertama DEA dengan asumsi CRS (Constant Return to Scale). Kedua penghitungan efisiensi dengan pendekatan VRS (Variable Return to Scale) atau BCC (Banker Charnes Cooper) yang dikenalkan pertama kali oleh Banker et al. (1984). Analisis data dalam penelitian ini dilakukan melalui: Pertama, melakukan estimasi tingkat efisiensi teknis dengan menggunakan model Data Envelopment Analysis (DEA), dan kemudian mengukur pertumbuhan produktivitas dengan menggunakan model Malmquist Productivity Index (MPI) Bank Umum di Indonesia selama periode 2010-2016.

Tabel 2. Variabel Input dan Output Penelitian

\begin{tabular}{ll}
\hline \multirow{3}{*}{ Variabel Input } & Dana Pihak Ketiga $(X 1)$ \\
& Aktiva Tetap $(X 2)$ \\
& Biaya Tenaga Kerja $(X 3)$ \\
\hline \multirow{3}{*}{ Variabel Output } & Aktiva Produktif $(Y 1)$ \\
& Pendapatan Bunga/ Bagi Hasil $(Y 2)$ \\
& Fee Based Income $(Y 3)$ \\
\hline
\end{tabular}

Data variabel input dan output diperoleh dari masing- masing laporan keuangan tahunan Bank Umum yang dipublikasikan pada website OJK dan website masing-masing bank antara periode 20102016. Data berbentuk time series mulai tahun 2010 hingga 2016. Adapun ringkasan statistik deskriptif variabel input-output Bank Umum di Indonesia pada tahun 2010-2016 disajikan pada table 3.

Tabel 3. Ringkasan Statistik Deskriptif Variabel Input-Output Bank Umum di Indonesia Tahun 2010-2016 (dalam jutaan)

\begin{tabular}{lrrrrr}
\hline \multicolumn{1}{c}{ Variabel } & $\begin{array}{c}\text { Jumlah } \\
\text { Bank }\end{array}$ & \multicolumn{1}{l}{ Mean } & $\begin{array}{l}\text { Standar } \\
\text { Deviasi }\end{array}$ & Minimum & \multicolumn{1}{c}{ Maximum } \\
\hline Dana Pihak Ketiga & 115 & 29.776 .806 & 81.956 .993 & 14.405 & 676.387 .261 \\
Aktiva Tetap & 115 & 18.853 .214 & 84.795 .716 & 1.794 & 910.063 .409 \\
Biaya Tenaga Kerja & 115 & 609.779 & 1.573 .243 & 2.294 & 15.970 .288 \\
Aktiva Produktif & 115 & 28.322 .489 & 73.191 .541 & 39.569 & 586.675 .437 \\
Bunga \& Bagi Hasil & 115 & 5.233 .779 & 29.753 .695 & 3.332 & 487.269 .006 \\
Fee Based Income & 115 & 423.304 & 1.442 .238 & 1,00 & 16.139 .975 \\
\hline
\end{tabular}

\section{Diskusi dan Pembahasan}

\section{Efisiensi Bank Umum Berdasarkan Pendekatan DEA}

Pendekatan DEA dengan orientasi input-output diterapkan pada data panel, dari 115 Bank Umum di Indonesia pada tahun 2010-2016, yang terdiri dari Bank Umum Konvensional (BUK) sebanyak 104 Bank dan Bank Umum Syariah (BUS) sebanyak 11 Bank. Dengan demikian jumlah keseluruhan observasi untuk menghitung nilai efisiensi seluruh unit perbankan tersebut adalah 1144. Di muka telah diuraikan, bahwa metode non parametrik dibagi dua: (i) berdasarkan asumsi Return to Scale (RTS), yaitu Model Constant Return to Scale (CRS) dan (ii) Model Variable Return to Scale (VRS). Dengan melakukan estimasi frontier menggunakan pendekatan CRS dan VRS, maka dapat melakukan dekomposisi Technical Efficiency pada pendekatan CRS (TE $\mathrm{CRS}_{\mathrm{C}}$ ) menjadi Pure Technical Efficiency (TEVRS) dan Scale Efficiency. Analisis efisiensi frontier merupakan analisis best practice dari keseluruhan dataset yang digunakan dengan menggunakan pendekatan input-output. Nilai efisiensinya adalah perbandingan dari seluruh bank (unit bisnis) dan tahun pengamatannya. Pendekatan ini memberikan output paling sederhana, dapat dibandingkan antar unit bisnis secara langsung, dan dapat melacak tingkat efisiensi sebuah bank. Hal ini secara eksplisit mengasumsikan bahwa teknologi adalah konstan dari waktu ke waktu. Skor efisiensi DEA berkisar antara 0 dan 1 (atau 0\% dan 100\%), di mana 1 (100\%) mewakili efisiensi penuh (fully efficient firm) atau perusahaan 
yang paling efisien secara teknis (fully technical efficient), dan kurang dari 100\% mewakili tidak efisien (inefficient firm) atau perusahaan yang tidak efisien secara teknis (technical inefficient).

Ringkasan statistik deskriptif hasil estimasi tingkat efisiensi Bank Umum di Indonesia dapat dilihat pada Tabel 4.

Table 4. Summary of efficiency score (all banks)

\begin{tabular}{|c|c|c|c|c|}
\hline Efficiency Measures & Mean & Minimum & Maximum & SD \\
\hline \multicolumn{5}{|l|}{ Panel 1: all banks 2010} \\
\hline Technical efficiency (TE) & 0.279 & 0.086 & 1.000 & 0.177 \\
\hline Pure technical efficiency (PTE) & 0.345 & 0.104 & 1.000 & 0.244 \\
\hline Scale efficiency (SE) & 0.878 & 0.269 & 1.000 & 0.167 \\
\hline \multicolumn{5}{|l|}{ Panel 2: all banks 2011} \\
\hline Technical efficiency (TE) & 0.272 & 0.100 & 1.000 & 0.171 \\
\hline Pure technical efficiency (PTE) & 0.333 & 0.100 & 1.000 & 0.223 \\
\hline Scale efficiency (SE) & 0.880 & 0.266 & 1.000 & 0.172 \\
\hline \multicolumn{5}{|l|}{ Panel 3: all banks 2012} \\
\hline Technical efficiency (TE) & 0.279 & 0.106 & 1.000 & 0.170 \\
\hline Pure technical efficiency (PTE) & 0.347 & 0.136 & 1.000 & 0.228 \\
\hline Scale efficiency (SE) & 0.873 & 0.255 & 1.000 & 0.184 \\
\hline \multicolumn{5}{|l|}{ Panel 4: all banks 2013} \\
\hline Technical efficiency (TE) & 0.296 & 0.125 & 1.000 & 0.192 \\
\hline Pure technical efficiency (PTE) & 0.378 & 0.142 & 1.000 & 0.259 \\
\hline Scale efficiency (SE) & 0.860 & 0.249 & 1.000 & 0.197 \\
\hline \multicolumn{5}{|l|}{ Panel 5: all banks 2014} \\
\hline Technical efficiency (TE) & 0.241 & 0.096 & 1.000 & 0.103 \\
\hline Pure technical efficiency (PTE) & 0.321 & 0.096 & 1.000 & 0.217 \\
\hline Scale efficiency (SE) & 0.867 & 0.256 & 1.000 & 0.207 \\
\hline \multicolumn{5}{|l|}{ Panel 6: all banks 2015} \\
\hline Technical efficiency (TE) & 0.250 & 0.126 & 0.999 & 0.104 \\
\hline Pure technical efficiency (PTE) & 0.323 & 0.129 & 1.000 & 0.202 \\
\hline Scale efficiency (SE) & 0.872 & 0.239 & 1.000 & 0.201 \\
\hline \multicolumn{5}{|l|}{ Panel 7: all banks 2016} \\
\hline Technical efficiency (TE) & 0.253 & 0.128 & 1.000 & 0.103 \\
\hline Pure technical efficiency (PTE) & 0.327 & 0.129 & 1.000 & 0.212 \\
\hline Scale efficiency (SE) & 0.877 & 0.241 & 1.000 & 0.201 \\
\hline \multicolumn{5}{|l|}{ Panel 8: all banks all years } \\
\hline Technical efficiency (TE) & 0.269 & 0.086 & 1.000 & 0.158 \\
\hline Pure technical efficiency (PTE) & 0.335 & 0.096 & 1.000 & 0.221 \\
\hline Scale efficiency (SE) & 0.879 & 0.239 & 1.000 & 0.178 \\
\hline
\end{tabular}

Tabel 4 di atas, menggambarkan ringkasan rerata skor efisiensi seluruh Bank Umum (Konvensional dan Syariah) di Indonesia dari tahun 2010-2016, dan rerata efisiensi seluruh bank dari rerata semua tahun sepanjang periode penelitian (all banks all years). Efisiensi Teknis (Technical Efficiency) berfluktuasi sepanjang periode penelitian, akan tetapi mulai tahun 2014 hingga akhir periode penelitian 2016 efisiensi teknis ini relatif mengalami peningkatan. Dari tabel di atas menunjukkan, bahwa industri perbankan di Indonesia telah memperlihatkan rerata technical efficiency secara keseluruhan (overall) sepanjang periode penelitian adalah 26,9 persen. Hal ini memberi kesan, bahwa melalui implementasi praktik manajemen yang lebih baik, Bank Umum di 
Indonesia dapat menghasilkan output dengan volume yang sama (identical volume), dengan hanya menggunakan 26,9 persen dari jumlah input. Di samping itu jumlah bank umum yang mencapai efisiensi teknis sama dengan atau di atas rerata (high efficiency) sebanyak 34 bank umum atau 29,56 persen dari jumlah 115 bank. Hal ini dapat diartikan bahwa sekitar 70 persen hypothetical relatif pangsa pasar kredit di Indonesia dikuasai oleh hanya 29,56 persen bank umum. Sementara itu sekitar 30 persen sisa pangsa pasar kredit diperebutkan oleh sebagian besar bank yakni 70,44 persen bank umum.

Table 5. Summary of efficiency score (conventional banks)

\begin{tabular}{|c|c|c|c|c|}
\hline Efficiency Measures & Mean & Minimum & Maximum & SD \\
\hline \multicolumn{5}{|l|}{ Panel 1: conventional banks 2010} \\
\hline Technical efficiency (TE) & 0.277 & 0.086 & 1.000 & 0.168 \\
\hline Pure technical efficiency (PTE) & 0.344 & 0.104 & 1.000 & 0.237 \\
\hline Scale efficiency (SE) & 0.875 & 0.269 & 1.000 & 0.171 \\
\hline \multicolumn{5}{|l|}{ Panel 2: conventional banks 2011} \\
\hline Technical efficiency (TE) & 0.272 & 0.100 & 1.000 & 0.170 \\
\hline Pure technical efficiency (PTE) & 0.336 & 0.100 & 1.000 & 0.226 \\
\hline Scale efficiency (SE) & 0.876 & 0.266 & 1.000 & 0.177 \\
\hline \multicolumn{5}{|l|}{ Panel 3: conventional banks 2012} \\
\hline Technical efficiency (TE) & 0.280 & 0.106 & 1.000 & 0.170 \\
\hline Pure technical efficiency (PTE) & 0.351 & 0.136 & 1.000 & 0.232 \\
\hline Scale efficiency (SE) & 0.868 & 0.255 & 1.000 & 0.188 \\
\hline \multicolumn{5}{|l|}{ Panel 4: conventional banks 2013} \\
\hline Technical efficiency (TE) & 0.298 & 0.125 & 1.000 & 0.190 \\
\hline Pure technical efficiency (PTE) & 0.384 & 0.142 & 1.000 & 0.261 \\
\hline Scale efficiency (SE) & 0.856 & 0.249 & 1.000 & 0.202 \\
\hline \multicolumn{5}{|l|}{ Panel 5: conventional banks 2014} \\
\hline Technical efficiency (TE) & 0.247 & 0.096 & 1.000 & 0.105 \\
\hline Pure technical efficiency (PTE) & 0.332 & 0.096 & 1.000 & 0.222 \\
\hline Scale efficiency (SE) & 0.861 & 0.256 & 1.000 & 0.214 \\
\hline \multicolumn{5}{|l|}{ Panel 6: conventional banks 2015} \\
\hline Technical efficiency (TE) & 0.254 & 0.126 & 0.999 & 0.107 \\
\hline Pure technical efficiency (PTE) & 0.333 & 0.129 & 1.000 & 0.208 \\
\hline Scale efficiency (SE) & 0.864 & 0.239 & 1.000 & 0.207 \\
\hline \multicolumn{5}{|l|}{ Panel 7: conventional banks 2016} \\
\hline Technical efficiency (TE) & 0.253 & 0.117 & 1.000 & 0.107 \\
\hline Pure technical efficiency (PTE) & 0.313 & 0.127 & 1.000 & 0.208 \\
\hline Scale efficiency (SE) & 0.853 & 0.237 & 1.000 & 0.207 \\
\hline \multicolumn{5}{|c|}{ Panel 8: conventional banks all years } \\
\hline Technical efficiency (TE) & 0.263 & 0.086 & 1.000 & 0.158 \\
\hline Pure technical efficiency (PTE) & 0.333 & 0.096 & 1.000 & 0.223 \\
\hline Scale efficiency (SE) & 0.867 & 0.237 & 1.000 & 0.182 \\
\hline
\end{tabular}

Adapun scale efficiency dan pure tecnical efficiency menunjukkan bahwa pure tecnical inefficiency melebihi scale inefficiency pada industri perbankan di Indonesia sepanjang periode penelitian. Pada umumnya temuan penelitian ini tampak dari sepanjang periode penelitian, bahwa industri perbankan di Indonesia adalah managerially incompetent dalam menggunakan sumber daya 
input secara efektif sekalipun mereka telah beroperasi pada skala operasi optimal yang layak (reasonably optimal scale of operation).

Di sisi lain efisiensi seluruh Bank Umum di Indonesia sepanjang periode penelitian menunjukkan variabilitas yang kecil (relatif homogen), karena seluruh standar deviasinya mulai dari panel 1 sampai dengan panel 8 pada Tabel 4 di atas lebih kecil dari pada keseluruhan reratanya (mean). Hal ini menunjukkan peningkatan efisiensi yang relatif lambat dan rendah di antara kelompok Bank Umum di Indonesia setelah terjadinya dampak krisis keuangan global.

Selanjutnya ringkasan statistik deskriptif Hasil Estimasi Tingkat Efisiensi Bank Umum Konvensional di Indonesia dapat dilihat pada Tabel 5. Tabel tersebut menggambarkan ringkasan rerata skor efisiensi seluruh Bank Umum Konvensional (BUK) di Indonesia dari tahun 2010-2016, dan rerata efisiensi seluruh bank dari rerata semua tahun sepanjang periode penelitian (all banks all years). Efisiensi Teknis (Technical Efficiency) berfluktuasi sepanjang periode penelitian. Dari tabel di atas menunjukkan, bahwa Bank Umum Konvensional di Indonesia telah memperlihatkan rerata technical efficiency secara keseluruhan (overall) sepanjang periode penelitian adalah 26,3 persen. Hal ini memberi kesan, bahwa melalui implementasi praktik manajemen yang lebih baik Bank Umum Konvensional di Indonesia dapat mengurangi inputnya dengan sekurang-kurangnya 73,7 persen, dan masih mampu menghasilkan volume output yang sama/tetap tidak berubah. Atau dengan kata lain Bank Umum Konvensional di Indonesia dapat menghasilkan output dengan volume yang sama (identical volume), dengan hanya menggunakan 26,3 persen dari jumlah input.

Adapun scale efficiency dan pure tecnical efficiency menunjukkan bahwa pure technical inefficiency melebihi scale inefficiency pada Bank Umum Konvensional di Indonesia sepanjang periode penelitian. Di sisi lain efisiensi seluruh Bank Umum Konvensional di Indonesia sepanjang periode penelitian menunjukkan variabilitas yang kecil (relatif homogen), karena seluruh standar deviasinya mulai dari panel 1 sampai dengan panel 8 pada Tabel 5, lebih kecil dari pada keseluruhan reratanya (mean). Hal ini menunjukkan peningkatan efisiensi yang relatif lambat dan rendah di antara kelompok Bank Umum Konvensional di Indonesia.

Selanjutnya ringkasan statistik deskriptif Hasil Estimasi Tingkat Efisiensi Bank Umum Syariah di Indonesia dapat dilihat pada Tabel 6. Tabel tersebut menggambarkan ringkasan rerata skor efisiensi seluruh Bank Umum Syariah (BUS) di Indonesia dari tahun 2010-2016, dan rerata efisiensi seluruh bank dari rerata semua tahun sepanjang periode penelitian (all banks all years). Efisiensi Teknis (Technical Efficiency) berfluktuasi sepanjang periode penelitian, dengan nilai rerata terendah pada tahun 2014 yakni hanya 17,8 persen. Fluktuasi efisiensi pada Bank Umum Syariah di Indonesia sepanjang periode penelitian, bisa jadi diakibatkan karena dampak terjadinya krisis ekonomi terutama yang bersumber dari dalam negeri.

Dari tabel tersebut ditunjukkan, bahwa Bank Umum Syariah di Indonesia telah memperlihatkan rerata technical efficiency secara keseluruhan (overall) sepanjang periode penelitian adalah 25,1 persen. Hal ini dapat dibaca, bahwa melalui implementasi praktik manajemen yang lebih baik Bank Umum Syariah di Indonesia dapat menghasilkan output dengan volume yang sama (identical volume), dengan hanya menggunakan 25,1 persen dari jumlah input saja. Dalam hal ini Bank Umum Syariah lebih tidak efisien dibandingkan dengan Bank Umum Konvensional.

Adapun scale efficiency dan pure tecnical efficiency menunjukkan bahwa pure tecnical inefficiency melebihi scale inefficiency pada Bank Umum Syariah di Indonesia sepanjang periode penelitian. Di sisi lain efisiensi seluruh Bank Umum Syariah di Indonesia sepanjang periode penelitian menunjukkan variabilitas yang kecil (relatif homogen), karena seluruh standar deviasinya mulai dari panel 1 sampai dengan panel 8 pada Tabel 6, lebih kecil dari pada keseluruhan reratanya (mean). Hal ini menunjukkan peningkatan efisiensi yang relatif lambat dan rendah di antara kelompok Bank Umum Syariah di Indonesia setelah terjadinya dampak krisis keuangan global. 


\section{Analisis Pertumbuhan Produktivitas Bank Umum}

Untuk menganalisis tingkat pertumbuhan produktivitas Bank Umum di Indonesia menggunakan pendekatan Malmquist Total Factor Productivity Index (MTFPI). Produktivitas total atau biasa disebut dengan Total Factor Productivity (TFP) mengukur hubungan antara output dengan beberapa input secara bersama-sama. Hubungan tersebut dinyatakan dalam rasio dari indeks output terhadap indeks input agregat. Jika rasio meningkat berarti lebih banyak output dapat diproduksi menggunakan jumlah input tertentu, atau sejumlah output tertentu dapat diproduksi dengan menggunakan lebih sedikit input.

Table 6. Summary of efficiency score (Islamic banks)

\begin{tabular}{|c|c|c|c|c|}
\hline Efficiency Measures & Mean & Minimum & Maximum & SD \\
\hline \multicolumn{5}{|l|}{ Panel 1: Islamic banks 2010} \\
\hline Technical efficiency (TE) & 0.309 & 0.139 & 1.000 & 0.266 \\
\hline Pure technical efficiency (PTE) & 0.356 & 0.144 & 1.000 & 0.322 \\
\hline Scale efficiency (SE) & 0.910 & 0.629 & 1.000 & 0.116 \\
\hline \multicolumn{5}{|l|}{ Panel 2: Islamic banks 2011} \\
\hline Technical efficiency (TE) & 0.272 & 0.131 & 0.789 & 0.189 \\
\hline Pure technical efficiency (PTE) & 0.295 & 0.131 & 0.817 & 0.195 \\
\hline Scale efficiency (SE) & 0.926 & 0.723 & 0.999 & 0.092 \\
\hline \multicolumn{5}{|l|}{ Panel 3: Islamic banks 2012} \\
\hline Technical efficiency (TE) & 0.269 & 0.155 & 0.781 & 0.176 \\
\hline Pure technical efficiency (PTE) & 0.293 & 0.155 & 0.816 & 0.185 \\
\hline Scale efficiency (SE) & 0.932 & 0.688 & 0.998 & 0.114 \\
\hline \multicolumn{5}{|l|}{ Panel 4: Islamic banks 2013} \\
\hline Technical efficiency (TE) & 0.278 & 0.161 & 0.923 & 0.217 \\
\hline Pure technical efficiency (PTE) & 0.312 & 0.162 & 1.000 & 0.237 \\
\hline Scale efficiency (SE) & 0.907 & 0.638 & 0.997 & 0.131 \\
\hline \multicolumn{5}{|l|}{ Panel 5: Islamic banks 2014} \\
\hline Technical efficiency (TE) & 0.178 & 0.117 & 0.292 & 0.053 \\
\hline Pure technical efficiency (PTE) & 0.200 & 0.118 & 0.442 & 0.090 \\
\hline Scale efficiency (SE) & 0.928 & 0.661 & 0.999 & 0.110 \\
\hline \multicolumn{5}{|l|}{ Panel 6: Islamic banks 2015} \\
\hline Technical efficiency (TE) & 0.205 & 0.141 & 0.313 & 0.051 \\
\hline Pure technical efficiency (PTE) & 0.213 & 0.142 & 0.317 & 0.050 \\
\hline Scale efficiency (SE) & 0.961 & 0.812 & 0.999 & 0.064 \\
\hline \multicolumn{5}{|l|}{ Panel 7: Islamic banks 2016} \\
\hline Technical efficiency (TE) & 0.215 & 0.143 & 0.411 & 0.053 \\
\hline Pure technical efficiency (PTE) & 0.223 & 0.147 & 0.417 & 0.051 \\
\hline Scale efficiency (SE) & 0.969 & 0.827 & 0.999 & 0.063 \\
\hline \multicolumn{5}{|l|}{ Panel 8: Islamic banks all years } \\
\hline Technical efficiency (TE) & 0.251 & 0.117 & 1.000 & 0.169 \\
\hline Pure technical efficiency (PTE) & 0.279 & 0.118 & 1.000 & 0.195 \\
\hline Scale efficiency (SE) & 0.929 & 0.629 & 1.000 & 0.113 \\
\hline
\end{tabular}

Malmquist Productivity Index (MPI) pertama kali dibuat oleh Sten Malmquist pada 1953 untuk mengukur produktivitas. Namun dalam perkembangannya, MPI ini diperkenalkan oleh Caves et.al (1982). Ada dua hal yang dihitung dalam pengukuran indeks Malmquist yaitu efek catch-up dan efek frontier shift. Efek catch-up mengukur tingkat perubahan efisiensi (efficiency change) relatif dari periode 1 ke periode 2. Sementara itu efek frontier shift mengukur tingkat perubahan teknologi 
(technological change) yang merupakan kombinasi input dan output dari periode 1 ke periode 2 . Efek frontier shift sering disebut sebagai efek inovasi (innovation effect).

MPI merupakan indeks bilateral yang digunakan untuk membandingkan teknologi produksi dua unsur ekonomi, dan berlandaskan pada konsep fungsi produksi (production function) yang mengukur fungsi produksi maksimum dengan batasan input yang sudah ditentukan. MPI memiliki beberapa karakteristik yang menguntungkan. Pertama, indeks ini merupakan metode non-parametrik sehingga tidak membutuhkan spesifikasi bentuk fungsi produksi. Kedua, MPI tidak memerlukan asumsi perilaku ekonomi unit produksi seperti minimisasi biaya (cost minimization) atau maksimisasi profit (profit maximization), sehingga sangat berguna apabila tujuan dari produsen berbeda-beda atau tidak diketahui. Ketiga, penghitungan indeks ini tidak memerlukan data harga-harga (price of input and output) yang seringkali tidak tersedia. Keempat, MTFPI dapat didekomposisi menjadi dua komponen yaitu Technical Efficiency Change (EFFCH) dan Technological Change (TECHCH). Menurut Avenzora (2008) hal ini sangat berguna karena analisis dapat dilakukan secara lebih spesifik berdasarkan komponen. EFFCH yang positif (positive efficiency change) merupakan bukti bahwa perubahan efisiensi mendekati frontier, sedangkan TECHCH yang positif (positive technological change) diketahui bahwa perubahan teknologi adalah sebagai inovasi (innovation). Kemudian EFFCH dapat didekomposisi menjadi dua komponen, yaitu Pure Technical Efficiency Change (PECH) dan Scale Efficiency Change (SECH) (Fare et al., 1994).

Tabel 7 menggambarkan hasil estimasi nilai Indeks Produktivitas Malmquist atau Malmquist Productivity Index (MPI) dari Bank Umum di Indonesia yang termasuk dalam observasi.

Tabel 7. Productivity Index of Indonesian Banking Industry

\begin{tabular}{|c|c|c|c|c|c|}
\hline Banks Productivity & EFFCH & TECH & $\mathrm{PECH}$ & SECH & TFPCH \\
\hline \multicolumn{6}{|l|}{ Panel 1: All banks } \\
\hline 2011 & 1.334 & 0.739 & 1.169 & 1.141 & 0.986 \\
\hline 2012 & 1.050 & 1.001 & 0.980 & 1.072 & 1.052 \\
\hline 2013 & 0.922 & 1.147 & 1.025 & 0.899 & 1.057 \\
\hline 2014 & 1.066 & 0.940 & 1.032 & 1.033 & 1.002 \\
\hline 2015 & 0.883 & 1.058 & 0.918 & 0.962 & 0.935 \\
\hline 2016 & 0.815 & 1.001 & 0.917 & 0.931 & 0.816 \\
\hline Geometric mean & 1.033 & 0.967 & 1.021 & 1.017 & 1.003 \\
\hline \multicolumn{6}{|c|}{ Panel 2: Conventional banks } \\
\hline 2011 & 1.336 & 0.712 & 1.198 & 1.115 & 0.951 \\
\hline 2012 & 0.993 & 1.091 & 0.948 & 1.048 & 1.084 \\
\hline 2013 & 0.981 & 1.069 & 1.081 & 0.907 & 1.049 \\
\hline 2014 & 1.033 & 0.998 & 0.998 & 1.035 & 1.031 \\
\hline 2015 & 0.867 & 1.062 & 0.920 & 0.943 & 0.921 \\
\hline 2016 & 0.998 & 0.997 & 0.977 & 0.983 & 0.995 \\
\hline Geometric mean & 1.030 & 0.973 & 1.021 & 1.005 & 1.004 \\
\hline \multicolumn{6}{|c|}{ Panel 3: Islamic banks } \\
\hline 2011 & 0.871 & 1.178 & 0.953 & 0.914 & 1.026 \\
\hline 2012 & 1.233 & 0.688 & 1.049 & 1.175 & 0.847 \\
\hline 2013 & 0.936 & 1.139 & 0.926 & 1.010 & 1.066 \\
\hline 2014 & 1.081 & 0.669 & 1.071 & 1.009 & 0.723 \\
\hline 2015 & 0.962 & 1.124 & 0.992 & 0.969 & 1.081 \\
\hline 2016 & 1.002 & 1.007 & 1.012 & 0.969 & 1.011 \\
\hline Geometric mean & 1.009 & 0.931 & 0.997 & 1.015 & 0.943 \\
\hline
\end{tabular}

Note: Effch (efficiency change); Tech (Technical change); Pech (Pure efficiency change); Sech (Scale efficiency change); Tfpch (Total factor productivity change)

Pada Tabel 7 di atas menunjukkan bahwa semua indeks dikategorikan ke dalam beberapa panel antara lain, Panel 1 : Bank Umum (BUK dan BUS), Panel 2 : Bank Konvensional, dan Panel 3 : 
Bank Syariah. Malmquist TFPCH dan komponennya adalah didasarkan pada skor awal, yaitu 1.000 untuk tahun 2010 sebagai tahun dasar. Jika skor MTFPI lebih besar dari 1.000, maka produktivitas mengalami peningkatan pertumbuhan (growth), jika MTFPI sama dengan 1.000, maka produktivitas mengalami stagnasi pertumbuhan (stagnation), jika MTFPI lebih kecil dari 1.000, maka produktivitas mengalami penurunan pertumbuhan (decline).

Panel 1 Tabel 7 di atas memperlihatkan peningkatan pertumbuhan produktivitas, sebagaimana ditunjukkan oleh nilai TFPCH sebesar 1.003. Kenaikan TFPCH yang sangat kecil ini menunjukkan rendahnya tingkat inovasi (low level of innovation) pada sektor perbankan di Indonesia. Hal ini dibuktikan dengan adanya penurunan (regress) TECHCH dengan nilai 0.967. Nilai lebih dari $1 \mathrm{TECHCH}$ tidak cukup untuk mendorong seluruh level TECHCH pada sektor perbankan di Indonesia dari tahun 2010 sampai dengan tahun 2016. Kenaikan dan penurunan produktivitas tersebut berdampak pada rerata peningkatan pertumbuhan produktivitas yang sangat kecil, yaitu sebesar 0,3 persen (1.003) yang merupakan akibat rerata keseluruhan kenaikan EFFCH hanya sebesar 3,3 persen (1.033) berdasarkan hasil geometric mean. Dengan demikian rendahnya peningkatan pertumbuhan produktivitas terkait dengan skala dan terkait dengan managerial inefficiency, termasuk pada sektor perbankan di Indonesia secara keseluruhan inefisien dalam memonitor biaya-biayanya.

Pada Panel 2 dari Tabel 7 dapat dilihat, bahwa peningkatan pertumbuhan produktivitas Bank Umum Konvensional sebesar 0,4 persen atau dengan nilai TFPCH 1.004. Kenaikan produktivitas yang sangat kecil ini menunjukkan rendahnya tingkat inovasi (low level of innovation) pada sektor perbankan di Indonesia. Hal ini dibuktikan dengan adanya penurunan (regress) TECHCH dengan nilai 0.973. Kenaikan dan penurunan produktivitas tersebut berdampak pada rerata peningkatan pertumbuhan produktivitas yang sangat kecil, yaitu sebesar 0,4 persen yang merupakan akibat rerata keseluruhan kenaikan EFFCH yang hanya sebesar 3 persen (nilai 1.030) berdasarkan hasil geometric mean. Dengan demikian rendahnya peningkatan pertumbuhan produktivitas adalah terkait dengan skala dan terkait dengan managerial inefficiency. Pada Bank Umum Konvensional terjadi inefisien dalam memantau (monitoring) biaya-biayanya.

Pada Panel 3 dari Tabel 7 di atas, Bank Umum Syariah tampak mengalami penurunan tingkat pertumbuhan produktivitas (decline), sebagaimana ditunjukkan oleh penurunan TFPCH menjadi hanya 0.943 berdasarkan hasil geometric mean. Hal ini diakibatkan terutama oleh penurunan TECHCH sebesar 6.9 persen dan diakibatkan oleh penurunan indeks PEFFCH sebesar 0,3 persen. Penurunan TECHCH menunjukkan rendahnya tingkat inovasi seperti online banking, financial technology (fintech) dan factor lain semacamnya. Indeks EFFCH menunjukkan kenaikan sebesar 0,9 persen, yang sumber utama kenaikannya adalah diakibatkan oleh kenaikan SECH sebesar 1,2 persen.

Akhirnya dari hasil analisis ini sangat menarik untuk menjadi catatan, bahwa terjadi kenaikan produktivitas yang sangat rendah, dan bahkan terjadi penurunan pertumbuhan produktivitas Bank Umum (Konvensional dan Syariah) di Indonesia dari tahun 2011 sampai dengan tahun 2016. Pertumbuhan produktivitas tersebut pada umumnya diakibatkan oleh perubahan teknologi (technological change) sebagaimana digambarkan dengan adanya penurunan (decrease) tingkat TECHCH dalam semua kategori bank di Indonesia. Dengan demikian dibutuhkan pelayanan keuangan yang lebih inovatif dalam kaitannya dengan pengembangan teknologi perbankan (banking technology) seperti infrastruktur: telephone banking, mobile banking, dan internet banking (Kumar dan Gulati, 2008), dan juga aplikasi financial technology (fintech) dalam industri perbankan di Indonesia.

\section{Kesimpulan dan Rekomendasi}

Berdasarkan hasil analisis dan pembahasan terkait pengukuran tingkat efisiensi dan produktivitas industri perbankan Indonesia di atas, maka kesimpulan dalam penelitian ini adalah bahwa tingkat efisiensi Bank Umum (Konvensional dan Syariah) di Indonesia tahun 2010-2016, berdasarkan variabel-variabel input dan output yang telah dipilih berfluktuasi sepanjang periode penelitian. Fluktuasi efisiensi pada industri perbankan di Indonesia selama periode penelitian bisa terjadi karena 
(i) vulnerabilitas dampak krisis keuangan global dari luar Indonesia, dan (ii) krisis ekonomi yang bersumber dari dalam negeri. Hasil ini sesuai dengan temuan Zeitun dan Benjelloun (2013) yang meneliti tentang tingkat efisiensi perbankan pada negara ekonomi berkembang. Zeitun dan Benjelloun (2013) menyimpulkan bahwa krisis keuangan memiliki dampak yang signifikan terhadap tingkat efisiensi bank. Hasil penelitian lain yang dilakukan Kamarudin et al. (2016) menyimpulkan bahwa dampak krisis keuangan terhadap tingkat efisiensi perbankan justru terjadi pasca krisis, bukan pada saat terjadi krisis. Hal ini disebabkan adanya time lag atau selang waktu hingga dampaknya mulai terasa pada industri keuangan dan perbankan.

Tingkat produktivitas Bank Umum (Kovensional dan Syariah) di Indonesia tahun 2010-2016, berdasarkan pendekatan Malmquist Productivity Index menunjukkan bahwa selama durasi penelitian Bank Umum di Indonesia memperlihatkan peningkatan pertumbuhan produktivitas meskipun sangat kecil, sebagaimana ditunjukkan oleh kenaikan TFPCH sebesar 0.3 persen. Kenaikan TFPCH yang sangat kecil ini menunjukkan rendahnya tingkat inovasi (low level of innovation) pada sektor perbankan di Indonesia. Hal ini dibuktikan dengan adanya penurunan (regress) TECHCH. Artinya, stagnasi tingkat produktivitas industri perbankan di Indonesia diakibatkan rendahnya tingkat perubahan teknologi (Technological change) alih-alih penurunan tingkat efisiensi (Efficiency change). Oleh karenanya, isu financial technology saat ini cukup relevan dengan hasil penelitian ini.

Jumlah bank umum yang mencapai efisiensi teknis sama dengan atau di atas rerata (high efficiency) sebanyak 34 (29,56\%) bank umum dari sejumlah 115 bank. Hal ini berarti 70,44 persen hypothetical relatif pangsa pasar kredit perbankan dikuasai oleh hanya 29,06 persen bank umum. Sementara itu sekitar 30 persen sisa pangsa pasar kredit diperebutkan oleh sebagian besar bank yakni sejumlah 70,44 persen bank umum. Hasil ini relatif mirip dengan "Hukum 80:20" penguasaan pangsa ekonomi. Temuan ini relevan dengan hasil penelitian Ascarya dan Yumanita (2007) yang menjelaskan bahwa selama kurun waktu 2003-2005, dari seluruh bank komersial di Indonesia yang berjumlah 110 bank, hanya 24 bank yang efisien pada tahun 2003 dan hanya ada 9 bank fully efisien pada 2004. Sisanya belum mencapai tingkat efisiensi maksimal baik dalam posisi decreasing maupun increasing return to scale.

Scale efficiency dan pure tecnical efficiency menunjukkan bahwa pure tecnical inefficiency melebihi scale inefficiency pada industri perbankan di Indonesia sepanjang periode penelitian. Pada umumnya temuan penelitian ini tampak dari sepanjang periode penelitian, bahwa industri perbankan di Indonesia adalah managerially incompetent dalam menggunakan sumber daya input secara efektif sekalipun mereka telah beroperasi pada skala operasi optimal yang layak (reasonably optimal scale of opreation). Dalam bahasa lain menurut Setiawan dan Bagaskara (2016) juga Setiawan dan Sherwin (2017), kondisi yang terjadi dalam perbankan adalah "bad management" yang berasal dari sumber internal bank.

Efisiensi seluruh Bank Umum di Indonesia sepanjang periode penelitian menunjukkan variabilitas yang kecil (relatif homogen), karena seluruh standar deviasinya mulai dari panel 1 sampai dengan panel 8 lebih kecil dari pada keseluruhan reratanya (mean). Hal ini menunjukkan peningkatan efisiensi yang relatif lambat dan rendah di antara kelompok Bank Umum di Indonesia setelah terjadinya dampak krisis keuangan global. Dampak krisis terhadap perkembangan industri perbankan memang cukup terasa. Seperti temuan riset yang dilakukan Said (2013) terhadap perbankan yang beroperasi di area MENA dan non-MENA. Said (2013) menemukan bahwa Bank Islam berukuran besar menunjukkan peningkatan tingkat efisiensi mulai 2006 hingga 2008 dan mengalami penurunan saat krisis 2009. Sementara itu, bank Islam berukuran sedang dan kecil memiliki nilai efisiensi yang lebih rendah.

Beberapa rekomendasi terkait pengukuran tingkat efisiensi dan produktivitas industri perbankan Indonesia di atas, adalah sebagai berikut: Temuan dari hasil analisis index produktivitas sangat menarik untuk menjadi catatan, bahwa kenaikan yang sangat rendah bahkan terjadi penurunan pertumbuhan produktivitas Bank Umum (BUK dan BUS) di Indonesia dari tahun 2010 sampai dengan tahun 2016, ditemukan bahwa pada umumnya diakibatkan oleh perubahan teknologi (technology 
change) sebagaimana digambarkan dengan adanya penurunan (decrease) tingkat TECHCH dalam semua kategori bank di Indonesia. Dengan demikian dibutuhkan pelayanan keuangan yang lebih inovatif dalam kaitannya dengan pengembangan teknologi perbankan (banking technology), seperti infrastruktur: telephone banking, mobile banking, dan internet banking (Kumar dan Gulati, 2008), juga fiancial technology (fintech) dalam industri perbankan di Indonesia. Rodoni et al. (2017) dalam penelitiannya juga menyimpulkan bahwa penyumbang produktivitas perbankan di Indonesia bukan dari aspek teknologi melainkan kinerja manajerial. Dalam risetnya, Rodoni et al. (2017) melakukan komparasi kondisi efisiensi dan produktivitas bank syariah pada tiga Negara yakni Indonesia, Malaysia dan Pakistan.

Sementara itu dari perspektif Bank Umum Syariah, ia relatif lebih baik dan memiliki peluang lebih besar untuk perbaikan (improvement) dibandingkan dengan Bank Umum Konvensional (Ascarya dan Yumanita (2007); Pradiknas dan Faturohman (2015)). Ada beberapa faktor yang menjadi penghambat berkembangnya industri perbankan syariah di Indonesia, yaitu: 1) Belum memadainya permodalan Bank Syariah; 2) Lemahnya pemahaman praktisi bank syariah; 3) Kurangnya dukungan pemerintah dan 4) Trust \& minat masyarakat terhadap bank syariah cenderung rendah (Rusydiana, 2016, Rusydiana \& Sanrego 2018). Oleh karenanya pihak terkait perlu perbaikan dari sisi permodalan, peningkatan kualitas SDM bank syariah, digitalisasi keuangan (Nurfalah \& Rusydiana, 2019), dan tidak kalah penting adalah support pemerintah.

\section{Daftar Pustaka}

Ascarya and Yumanita, Diana. 2007. "Analisis Efisiensi Perbankan Syariah di Indonesia dengan Data Envelopment Analysis”. TAZKIA Islamic Finance and Business Review, Vol.1, No.2, pp. 1-32.

Banker, R.D., Charnes, A., and Cooper, W.W. 1984. "Some Models for Estimating Technical and Scale Inefficiency in Data Envelopment Analysis”, Management Science, 30 (9), 1078-92

Caves D.W., Christensen, L.R., Diewert, W.E., 1982. The Economic Theory of Index Number and The Measurement of Input, Output and Productivity. Econometrica, 50 (6).

Charnes, A., Cooper, W.W., and Rhodes, E. 1978. "Measuring the Efficiency of Decision Making Units", European Journal of Operation Research, 2, 6, 429-44.

Coelli, T., Rao, D.S.P. and Battese, G.E. 1998. Introduction to Efficiency and Productivity Analysis, Kluwer Academic Publisher, Boston.

Coelli, T., Rao, D.S.P., Prasada Rao, Christoper J. O'Donnel and G.E. Battese. 2005. Introduction to Efficiency and Productivity Analysis, (Second Edition), Kluwer Academic Publishers, Boston.

Cooper, William W., Seiford, Lawrence M., and Tone, Koru. 1999. A Comprehensive Text with Models, Application, References and DEA-Solver Software, Kluwer Academic Publisher, Boston USA.

Cooper, Willam W., Seiford, L.M., Tone K., 2002. Data Envelopment Analysis. Kluwer Academic Press, Boston.

Cooper, William W., Lawrance M. Seiford and Joe Zhu. 2010. Handbook on Data Envelopment Analysis. London: Springer.

Farrell, M.L. 1957. "The Measurement of Productive Efficiency", Journal of The Royal Statistical Society, 120, p.253-281.

Hadad, M.D., Santoso, W., Mardanugraha, E., \& Illyas, D. 2003. “Analisis Efisiensi Industri Perbankan Indonesia: Penggunaan Metode Nonparametrik Data Envelopment Analysis (DEA)". Biro Stabilitas Sistem Keuangan Bank Indonesia. Research Paper, 7/5. 
Hassan, Kabir. 2003. "Cost, Profit and X-Efficiency of Islamic Banks in Pakistan, Iran and Sudan". Proceeding International Conference on Islamic Banking : Risk Management, Regulation and Supervision, Bank Indonesia, 30 September-2 Oktober 2003. Bank Indonesia. Jakarta.

Islamic Banker Association. 2017. Global Islamic Finance Report 2017.

Kamarudin, F., Sufian, F., and Nassir, A.M. 2016. "Global financial crisis, ownership and bank profit efficiency in the Bangladesh's state owned and private commercial banks", Contaduria y Administracion, Vol. 61, pp.705-745.

Kamath, G.B. 2007. "The intellectual capital performance of the Indian banking sector", Journal of Intellectual Capital, Vol. 8 Issue: 1, pp.96-123.

Kumar, S \& Gulati, R. 2008. "An Examination of Technical, Pure Technical and Scale Efficiencies in Indian Public Sector Banks Using Data Envelopment Analysis (DEA)", Eurasian Journal of Business and Economics, 1(2), 33- 69.

Maisaroh, Siti. 2015. "Pengaruh Intellectual Capital dan Islamicity Performance Index Terhadap Profitability Perbankan Syariah Indonesia”. Jurnal Fakultas Ekonomi UIN Malang.

Nurfalah, I. dan Rusydiana, Aam S. 2019. "Digitalisasi keuangan syariah menuju keuangan inklusif: Kerangka maqashid syariah", Ekspansi: Jurnal Ekonomi, Keuangan, Perbankan dan Akuntansi, Vol. 11, No. 1, pp. 55-76.

Nurfalah, I., Rusydiana, A.S., Laila, N., and Cahyono, E.F. 2018, "Early warning to banking crises in the dual financial system in Indonesia: The markov switching approach", JKAU: Islamic Economics, Vol.31, No.2, pp.133-156.

Otoritas Jasa Keuangan. 2018. Statistik Perbankan Syariah Indonesia April Tahun 2018.

Ozdemir, Asli. 2013. "Integrating analytic network process and data envelopment analysis for efficiency measurement of Turkish commercial banks". Banks and Bank Systems Volume 8 issue 2, 2013.

Pradiknas, T.Y., Faturohman, T. 2015. "Efficiency of Islamic banking compared to conventional banking: Evidence from Indonesia", Journal of Business and Management, Vol.4, No.5, pp.540-551.

Rani, L., Rusydiana, A., and Widiastuti, T. 2017. "Comparative analysis of Islamic bank's productivity and conventional bank's in Indonesia period 2008-2016". In 1st International Conference on Islamic Economics, Business and Philanthropy (ICIEBP 2017), pp. 118-123.

Rodoni, A., Salim, M.A., Amalia, E., and Rakhmadi, R.S. 2017. "Comparing efficiency and productivity in Islamic banking: Case study in Indonesia, Malaysia and Pakistan”, Al-Iqtishad: Journal of Islamic Economics, Vol.9, No.2, pp.227-242.

Rusydiana, Aam S. 2018. "Indeks Malmquist untuk pengukuran efisiensi dan produktivitas bank syariah di Indonesia”, Jurnal Ekonomi dan Pembangunan LIPI, Vol.26, No.1, pp.47-58.

Rusydiana, Aam S., and Sanrego, Y. D. 2018. "Measuring the performance of Islamic banking in Indonesia: An application of Maslahah efficiency quadrant (MEQ)". Journal of Monetary Economics and Finance, Vol 3 Special Issue, pp.103-130.

Rusydiana, Aam S. 2016. "Analisis masalah pengembangan perbankan syariah di Indonesia: Aplikasi metode analytic network process". Esensi: Jurnal Bisnis dan Manajemen, Vol. 6, No. 2, pp.237-246.

Rusydiana, A.S. dan Tim SMART Consulting. 2013. Mengukur Tingkat Efisiensi dengan Data Envelopment Analysis. Bogor: SMART Publishing. 
Said, Ali. 2013. "Risks and efficiency in the Islamic banking system: The case of selected Islamic banks in MENA region", International Journal of Economics and Financial Issues, Vol. 3, No. 1, pp.66-73.

Setiawan, C., and Bagaskara, B.P. 2016. "Non-performing financing (NPF) and cost efficiency of Islamic banks in Indonesia period 2012Q1 to 2015Q2", Journal of Emerging Issues in Economics, Finance and Banking, Vol.5, Issue 1.

Setiawan, C., and Sherwin, S.M. 2017. "Banks efficiency and the determinants of non-performing financing of full-fledged Islamic banks in Indonesia", Proceedings of 12th Asia-Pacific Business Research Conference 27-28 February 2017 Malaysia.

Shahreki, Javad, Nazar Dahmardeh and Mohammad Ali Ghasemi. 2012. "Efficiency Evaluation Bank Sepah Branches in Sistan and Baluchestan Province Using Data Envelopment Analysis". Interdisciplinary Journal of Contemporary Research in Business Vol. 4 No. 2, June 2012.

Shawtari, F.A.M., Kareem, M.A.A and Razak, S.H.A. 2014. "Efficiency and Stability Assessment of the Yemeni Banking Sector using Data Envelopment Window Analysis". Proceeding of the $12^{\text {th }}$ International Conference of DEA p.144-153. April 2014 Kuala Lumpur Malaysia.

Sherman, H.D. and Gold. 1985. "Bank Branch Operating Efficiency: Evaluation with Data Envelopment Analysis", Journal of Banking and Finance, 9, 279-315.

Tsolas, Ioannis E. and Dimitris I. Giokas. 2012. "Bank branch efficiency evaluation by means of least absolute deviations and DEA". Managerial Finance Vol 38 No. 8, 2012.

Yudistira, Donsyah. 2003. "Efficiency in Islamic Banking: an Empirical Analysis of 18 Banks". Proceeding International Conference on Islamic Banking : Risk Management, Regulation and Supervision, Bank Indonesia, 30 September-2 Oktober 2003. Bank Indonesia. Jakarta

Zeitun, R. And H. Benjelloun. 2013. "Efficiency of banks and the financial crisis in a developing economy: The case of Jordan". Journal of Finance, Accounting and Management, 4(1): 1-20. 